\title{
The Effect Of Compensation, Work Environment And The Transformational Leadership Style Toward Employee Performance (On Pd. Bpr Bkk Purwokerto)
}

\author{
Purnadi $^{1}$, Yudhistira Pradhipta Aryoko \\ \{purnadisept2019@gmail.com ${ }^{1}$,yudistirapradhipta@ump.ac.id ${ }^{3}$ \} \\ 1, 2,Faculty of Economics and Business, University of Muhammadiyah Purwokerto
}

\begin{abstract}
This study aims to analyze the effect of Compensation, Work Environment, and Transformational Leadership Style partially and simultaneously on Employee Performance in PD BPR BKK Purwokerto. The population of this research is 264 employees in PD BPR BKK Purwokerto. The sampling method used was purposive sampling, with a total of 134 samples with several criteria that have been required. Data collection using a questionnaire. Regression analysis results show Compensation, partially significant positive effect on Employee Performance, Work Environment partially significant positive effect on Employee Performance, Transformational Leadership Style partially significant positive effect on Employee Performance, simultaneously Compensation, Work Environment, and Transformational Leadership Style significantly on Employee Performance.

Keywords: Compensation, Work Environment, Transformational Leadership Styles and Employee Performance
\end{abstract}

\section{Introduction}

In this modern era, many companies are competing to become companies that excel in competition. Technological advances and intense competition in the era of globalization make the company will always adapt to changes that occur in the business environment. To respond to this, companies make their human resources their primary focus. It is because HR is the "heart" of a company.

Not only has a good strategy, but qualified human resources can support the company's goals. Qualified HR or employees will be able to put the company on a competitive track or even be a leader in the competition. The quality of human resources within the company must continue to be developed by companies that are adjusted to current developments. Employees can carry out work in a professional, responsible, and have the right attitude to help the company meet the increasingly complex needs of consumers.

Currently, there are various types of companies that compete to be superior compared to other companies, one of which is a regional company. According to RI Law Number 17 of 2003 concerning State Finances, regional companies are Regionally Owned Enterprises (BUMD), which are wholly or partly owned by the regional government. In Banyumas Regency, there are several regional companies, one of which is the Rural Credit Bank or BPR.

BPR is a financial institution that accepts deposits only in the form of time deposits, savings, and other forms of equalization and channeling funds as a business [22]. Since its 
inception, BPR has been focused on serving people in remote areas that have not been reached maximally by commercial bank services.

\section{Literature Review}

\subsection{Employee Performance}

Performance is a result of the achievements obtained by employee in the company, because they have carried out its duties and responsibilities with predetermined criteria so that the goals of the company could be achieved. Employee performance is vital, because through assesing the performance of the employee, the company will know how far the employees' ability to carry out the tasks assigned to them; however, managers do not want to achieve halfperformance.

Performance according to [16] was the work that can be achieved by a person or group of people in the organization, under their respective authorities and responsibilities, in the context of efforts to achieve the objectives of the relevant organization legally, not breaking the law and by morals and ethics. Another understanding, According to [13], Performance is the work of the quality and quantity achieved by an employee in carrying out their duties per the responsibilities given to him.

Meanwhile, according to [4] performance is the result or level of the overall success of a person during a specified period in carrying out the task compared with various possibilities, such as work standards, targets or targets, or Performance that has been determined in advance and has been agreed together. According to [3], several factors that affect Performance were:

a. Ability and Expertise

b. Knowledge

c. Work Plan

d. Personality

e. Work Motivation

f. Leadership Style

g. Organizational Culture

h. Job Satisfaction

i. Work Environment

j. Loyalty

k. Commitment

1. Work Discipline

\subsection{Compensation}

Compensation is something that the company gives to its employees, both financial and non-financial, directly or indirectly as a form of remuneration for its contribution to the company or organization. Compensation needs to be distinguished from salary and wages because the concept of compensation is not the same as the concept of salary or wages. Salary and Wages is a concrete form of compensation.

According to [3] in general, the purpose of granting compensation by the company were:
a. Give Employee Rights
b. Give a Sense Of Justice
c. Get Qualified Employees 
d. Retain Employees

e. Respect Employees

f. Cost Control

g. Meet Government Regulations

h. Avoid Conflict

According to [3], Compensation is a remuneration provided by the company to employees, both financial and non-financial. According to [26], Compensation is a direct or indirect, fair financial or non-financial award to employees for their contribution to achieving organizational goals. Meanwhile, according to [23], compensation is all income in the form of money, direct or indirect goods received by employees in return for being given to the company. According to [3], many benefits can be obtained with compensation:

a. Employee Loyalty Increases

b. Commitment to The Company Increases

c. Work Motivation Increases

d. Increased Morale

e. Employee Performance Has Improved

f. Work Conflicts Can Be Reduced

g. Give a Sense of Security

h. Give a Sense of Pride

i. The Process of The Company's Activities Runs Smoothly

\subsection{Work Environment}

The work environment is anything that exists around the workers that can influence or create morale in order to achieve the expected performance. According to [28] Environment includes institutions or coercion from outside the organization that potentially affect organizational Performance. According to [21], the work environment exists around the workers and affects them in carrying out the assigned tasks.

Another understanding, according to [5], work environment is the overall tools and materials faced, the surrounding environment in which a person works, his work methods, and his work arrangements both as individuals and as groups. According to [28] states that several factors could influence the organizational environment, such as:

a. Capacity

Capacity refers to circumstances in which the environment can support growth. A vibrant and growing environment will produce excess resources that can sustain an organization when relative scarcity occurs.

b. Volatility

Describe the degree of instability in the environment. A dynamic environment with a degree of change that is very unpredictable will make it difficult for management to make accurate predictions.

c. Complexity

Complexity is the degree of heterogeneity and concentration among environmental elements.

\subsection{Transformational Leadership Style}

Transformational leadership is a leader who could influence subordinates and provide inspiration and motivation to followers so that followers can work more than expected. Leadership is a reciprocal relationship between subordinates and superiors. 
According to [27], Transformational Leadership is a leader who stimulates and inspires (transforms) subordinates to achieve extraordinary results. Another understanding, according to [28], Transformational leadership style is a leader who inspires his followers to put aside their interests and have the ability to influence extraordinary. Meanwhile, according to [11], the Transformational leadership style is the behavior of leaders in influencing subordinates to want to work productively to achieve organizational goals.

According to [2], there are several dimensional factors of transformational leadership styles, such as:

a. Charisma (later changed to an ideal influence or idealized influence)

b. Inspiration (inspirational motivation)

c. Intellectual Development (intellectual stimulation)

d. Personal Attention (individualized consideration)

\subsection{Formulation of the problem}

Based on the description from the background above, the main issues in this study are:

a. Does Compensation have a positive and significant effect on Work Performance?

b. Does Work Environment have a positive and significant effect on Work Performance?

c. Does Transformational Leadership Style have a positive and significant effect on on Work Performance?

\subsection{Research Model Development}

Based on the description above can be described the following framework:

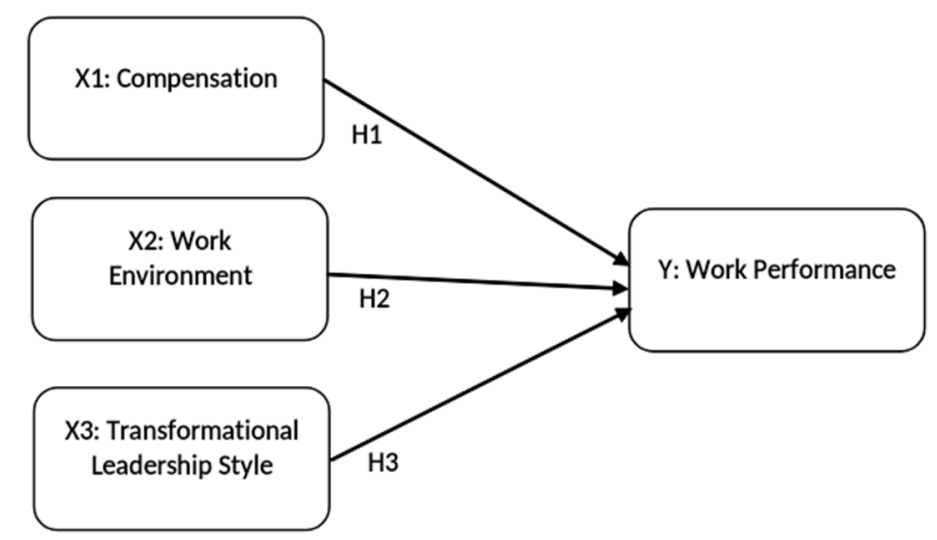

Fig.1. Framework

\section{Hypothesis:}

H1: Compensation have a positive and significant effect on Work Performance.

H2: Work Environment have a positive and significant effect on Work Performance.

H3: Transformational Leadership Style have a positive and significant effect on on Work Performance. 


\section{Method}

The method used in this research is quantitative - data obtained by distributing Likert scale questionnaires. The questionnaire was distributed directly to employees who included samples in each office in the entire Banyumas district to ensure that respondents were given enough time to answer questions and get a high response rate. All data collected was entered into a computer for further analysis using SPSS 24.

The population in this study was all PD. BPR BKK Purwokerto employees in Banyumas Regency. This research sample is permanent employees who have worked for at least one year, selected using purposive sampling techniques. We obtained a sample of 134 people.

\section{Results And Discussion}

Based on the results of the analysis of the data presented in the questionnaire, the following are the results obtained:

\subsection{Validity Test}

Based on the item validity test, which was conducted to test whether each question contained in the questionnaire could represent the indicators examined in each statement, the results were found that each factor had a positive correlation and the r-count value $>0.1427$. Then it can be ascertained that the research instruments used have good compilation validity.

\subsection{Reliability Test}

The reliability test that was carried out showed that every statement that exists produced a Cronbach Alpha value $>0.60$. It indicates that the research instrument used to measure every variable that exists can be reliable or reliable.

\subsection{Classic Assumption Test}

\subsubsection{Normality Test}

Normality test conducted shows that the probability / significance value ( $\mathrm{p}$-sig) indicates that $\mathrm{P}>0.05$. It shows that the regression model, the dependent and independent variables are normally distributed.

\subsubsection{Multicollinearity Test}

The multicollinearity test that has been done shows that the correlation value between independent variables (VIF) is 1.83 . There are no multicollinearity symptoms. Because if the VIF value $>10$, it means that there are multicollinearity symptoms in the data.

\subsubsection{Heteroscedasticity Test}

Heteroscedasticity test results that have been done show that the probability value (sig) for variable $\mathrm{X} 1=0.372$ while for variable $\mathrm{X} 2=0.287$ and for variable $\mathrm{X} 3=0.184$. It shows that there are no symptoms of heteroscedasticity. 


\subsection{Multiple Linear Regression Analysis}

\begin{tabular}{llr|r|}
\multicolumn{5}{c}{ Table 1. Multiple Linear Test Results Model } \\
\multicolumn{2}{l}{ Model } & Unstandardized Coefficients \\
& B & Std. Error \\
\hline 1 (Constant) & .788 & .288 \\
\cline { 2 - 4 } & Compensation (X1) & .319 & .075 \\
\cline { 2 - 4 } & Work Environment (X2) & .184 & .083 \\
\hline Transformational Leadership Style (X3) & .343 & .062 \\
\hline
\end{tabular}

Based on the regression analysis results, the equation of the multiple linear regression model is obtained as follows:

$$
\begin{array}{ll}
\mathrm{Y} & \alpha+\beta 1 \mathrm{X} 1+\beta 2 \mathrm{X} 2+\beta 3 \mathrm{X} 3+\mathrm{e} \\
& =0,788+0,319 \mathrm{X} 1+0,184 \mathrm{X} 2+0,343 \mathrm{X} 3+\mathrm{e}
\end{array}
$$

1. Based on the results of the regression equation above, it can be concluded that:

2. The intercept constant is 0.788 .

3. The Compensation Variable (X1) has a positive regression coefficient. It can be interpreted if there is an increase in the $\mathrm{X} 1$ variable, then the $\mathrm{Y}$ variable will also increase by 0.319 if the other independent variables remain.

4. The Work Environment Variable (X2) has a positive regression coefficient. Can be interpreted if there is an increase in variable $\mathrm{X} 1$, then the variable $\mathrm{Y}$ will also increase by 0.184 if the other independent variables remain.

5. The Transformational Leadership Style Variable (X2) has a positive regression coefficient. It can be interpreted if there is an increase in the variable X1, then the variable $\mathrm{Y}$ will also increase by 0.343 if the other independent variables remain.

\subsection{Coefficient of Determination}

The data analysis technique used in this study is multiple regression analysis with moderation using the absolute difference method. This test is done by regressing the absolute difference in the standardized independent variable with the variable hypothesized as a

\begin{tabular}{|c|c|c|c|c|}
\hline \multirow[b]{2}{*}{ Model } & \multicolumn{4}{|c|}{ Table 2. Model Summary } \\
\hline & $\mathrm{R}$ & $\begin{array}{c}\mathrm{R} \\
\text { Squa } \\
\text { re }\end{array}$ & $\begin{array}{l}\text { Adjuste } \\
\text { d R } \\
\text { Square }\end{array}$ & $\begin{array}{l}\text { Std. Error of } \\
\text { the Estimate }\end{array}$ \\
\hline 1 & $.764^{a}$ & .583 & .574 & .4377 \\
\hline
\end{tabular}
standardized moderating variable.

The magnitude of the coefficient of determination (Adjusted R Square) shows 0.574. It shows that simultaneously the independent variable Compensation (X1), Work Environment (X2), and Transformational Leadership Style (X3) affect the dependent variable Employee Performance (Y) by $57.4 \%$. Thus, the remaining $42.6 \%$ is influenced by other variables outside this study. 


\subsection{The T-test (Partial Test)}

Tab. 3. T-Test Results (Partial Test)

\begin{tabular}{r|r|r}
\hline $\begin{array}{c}\text { Standardized } \\
\text { Coefficients } \\
\text { Beta }\end{array}$ & $\mathrm{T}$ & \multicolumn{1}{c}{ Sig. } \\
\hline & 2.737 & .007 \\
\hline .311 & 4.226 & .000 \\
\hline .148 & 2.223 & .028 \\
\hline .436 & 5.514 & .000 \\
\hline
\end{tabular}

Dependent Variable: Employee Performance

T-test results show that the significance level of $\mathrm{t}$ for the variable $\mathrm{X} 1$ is 0,000 , which is smaller than the significance level of 0.05 and has a standardized beta value of 0.311 . It shows that the Compensation variable (X1) has a positive and significant effect on Employee Performance (Y).

T-test results indicate that the value of the significance level of $t$ for the $\mathrm{X} 2$ variable is 0.028 , which is smaller than the significance level of 0.05 and has a standardized beta value of 0.148. It shows that the Work Environment variable (X2) has a positive and significant effect on Employee Performance (Y).

T-test results indicate that the value of the significance level of $t$ for the $\mathrm{X} 3$ variable is 0,000 , which is smaller than the significance level of 0.05 and has a standardized beta value of 0.436. It shows that the Transformational Leadership Style (X3) variable has a positive and significant influence on Employee Performance (Y).

The validity test conducted showed that all variables, both dependent and independent, had a positive correlation and $\mathrm{r}$-count value $>0.1427$. The reliability test in this study was declared reliable because it showed a Cronbach Alpha X1 variable value of 0.781 ; X2 variable of 0.632 ; variable $\mathrm{X} 3$ was 0.908 , and variable $\mathrm{Y}$ was 0.813 .

The Compensation Variable (X1) has a positive regression coefficient. It can be interpreted if there is an increase in the $\mathrm{X} 1$ variable. The $\mathrm{Y}$ variable will also increase by the value of the regression coefficient, which is equal to 0.319 , assuming the other independent variables are fixed. Meanwhile, the Work Environment Variable (X2) has a positive regression coefficient. It can be interpreted if there is an increase in the $\mathrm{X} 2$ variable. The $\mathrm{Y}$ variable will also increase by the value of the regression coefficient, which equals 0.184 , assuming the other independent variables are fixed.

Moreover, the Transformational leadership style variable (X3) has a positive regression coefficient. It can be interpreted if there is an increase in the $\mathrm{X} 3$ variable. The $\mathrm{Y}$ variable will also increase by the value of the regression coefficient, which is equal to 0.343 , assuming the other independent variables are fixed.

The coefficient of determination (Adjusted R Square) shows 0.574. It shows the good enough effect between independent variables $\mathrm{X} 1, \mathrm{X} 2$, and $\mathrm{X} 3$ on the dependent variable $\mathrm{Y}$. $\mathrm{F}$ test results show that the variables $\mathrm{X} 1, \mathrm{X} 2$, and $\mathrm{X} 3$ have a significant positive effect on the $\mathrm{Y}$ variable.

T-test results indicate that the value of the level of significance $t$ for the variable $\mathrm{X} 1$ is equal to 0,000 . The value of the significance level of $t$ for variable $\mathrm{X} 2$ is 0.028 . Furthermore, the value of the significance level of $t$ for the $\mathrm{X} 3$ variable is 0,000 . It further supports other tests that have been carried out: the Compensation variable (X1), Work Environment (X2), 
and the Transformational Leadership Style have a positive and significant value on the Employee Performance variable.

\section{Conclusion}

Based on the results of data analysis and discussion of research results and the results of data testing that have been carried out, it can be drawn as follows:

1. Compensation (X1), Work Environment (X2), and Transformational Leadership Style (X3) simultaneously have a significant effect on Employee Performance (Y) in PD. BPR BKK Purwokerto.

2. Compensation (X1) has a positive and partially significant effect on Employee Performance (Y) in PD. BPR BKK Purwokerto.

3. Work Environment (X2) has a positive and partially significant effect on Employee Performance (Y) in PD BPR BKK Purwokerto.

4. Transformational Leadership Style (X3) has a positive and partially significant effect on Employee Performance (Y) in PD. BPR BKK Purwokerto.

Based on the results of the study and the conclusions available, the recommended recommendations are as follows:

1. For PD BPR BKK Purwokerto

a. Compensation

To give compensation both financial and non-financial, directly under the limits of PD. BPR BKK Purwokerto to pay employees to improve employee performance.

b. Work environment

They created a safe and comfortable work environment, especially at room temperature in PD. BPR BKK Purwokerto, so employees are eager to work.

c. Transformational Leadership Style

Leader PD. BPR BKK Purwokerto must always be supervised the Performance of each employee and help develop the personal strengths of its employees so that it works well.

d. Employee performance

With increasing side compensation, work environment, and transformational leadership style, over time, it will improve employee performance PD BPR BKK Purwokerto.

2. For Researchers

Future studies should broaden the research sample and add new research variables such as price, service quality, and consumer motivation so that the results obtained are expected to be generalizable.

\section{References}

[1] A. Effendy and J. R. Fitria, "Pengaruh Lingkungan Kerja Dan Stres Kerja Terhadap Kinerja Karyawan (Studi Kasus PT. Modernland Realty, Tbk)," JIMF (Jurnal Ilm. Manaj. Forkamma), vol. 2, no. 2, 2019. 
[2] Putranto and R. Wijayanti, "Pengaruh Gaya Kepemimpinan Transformasional, Kompensasi dan Komunikasi Organisasi Terhadap Kinerja Karyawan,” J. Econ. Manag. Account. Technol., vol. 1 , no.

[3] D. Kasmir, Manajemen Sumber Daya Manusia (Teori dan Praktik). 2016.

[4] D. P. B. Triyanti, "Pengaruh Gaya Kepemimpinan Transformasional Terhadap Kinerja Pegawai Pada Dinas Koperasi, Umkm, Perindustrian Dan Perdagangan Kabupaten Barito Timur," J. PubBis, vol. 3, no. 1, pp. 87-101, 2019.

[5] D. W. R. Rondo, R. A. M. Koleangan, and H. Tawas, "Pengaruh Kepribadian, Lingkungan Kerja Dan Penempatan Kerja Terhadap Kinerja Karyawan (Pada Pt. Bpr Prisma Dana Manado),” J. EMBA J. Ris. Ekon. Manajemen, Bisnis dan Akunt., vol. 6, no. 4, 2018.

[6] E. Prastyo, L. B. Hasiholan, and M. M. Warso, "Pengaruh Motivasi, Kepuasan, dan Lingkungan Kerja Terhadap Kinerja Karyawan Honorer Dinas Bina Marga Pengairan dan ESDM Kabupaten Jepara," J. Manage., vol. 2, no. 2, 2016.

[7] E. Y. Setiawan, "Pengaruh Gaya Kepemimpinan Transformasional dan Transaksional terhadap Kinerja Karyawan PT. Iss Indonesia di Rumah Sakit National Surabaya," J. Manaj. Magistra, vol. 1, no. 1, 2015.

[8] F. Fiansi and S. Sarifuddin, "Pengaruh Motivasi Dan Lingkungan Kerja Terhadap Kinerja Pegawai Pada Dinas Koperasi Dan Umkm Kabupaten Tolitoli,” J. Sinar Manaj., vol. 6, no. 2, pp. 141-145, 2019.

[9] F. O. Lestari, M. Musringah, and S. Irdiana, "Pengaruh Budaya Kaizen Dan Kompensasi Terhadap Kinerja Karyawan Kantor Pos Lumajang,” in Proceedings Progress Conference, 2018, vol. 1 , no. 1 , pp. 584-595.

[10] F. Y. S. Bagus, A. W. Sirait, T. F. Siburian, and O. S. B. Karo, "Pengaruh Kompetensi Dan Kompensasi Terhadap Kinerja Karyawan Pt. Bpr Nusantara Bona Pasogit 17 (Bank Bpr),” J. Mutiara Manaj., vol. 4, no. 1, pp. 316-322, 2019.

[11] G. Kusuma and E. Rahardja, "Pengaruh Gaya Kepemimpinan Transformasional, Budaya Organisasi dan Motivasi Kerja Terhadap Kinerja Karyawan (Studi Pada Karyawan PD BPR BKK Taman Pemalang),” Diponegoro J. Manag., vol. 7, no. 2, pp. 210-220, 2018.

[12] H. Sidanti, "pengaruh lingkungan kerja, disiplin kerja dan motivasi Kerja terhadap kinerja pegawai negeri sipil di Sekretariat DPRD kabupaten madiun," J. Jibeka, vol. 9, no. 1, pp. 44-53, 2015.

[13] IK. A. P. Putra and M. Subudi, "Pengaruh Gaya Kepemimpinan Transformasional dan Lingkungan Kerja Fisik terhadap Kinerja Karyawan PT BPR Pedungan,” E-Jurnal Manaj. Univ. Udayana, vol. 4, no.

[14] K. Al-Omari and H. Okasheh, "The influence of work environment on job performance: A case study of engineering company in Jordan,” Int. J. Appl. Eng. Res., vol. 12, no. 24, pp. 15544 15550, 2017.

[15] L. Lynawati, "Pengaruh Kompensasi, Stres Kerja, dan Komunikasi terhadap Kinerja Karyawan PT Bank Rakyat Indonesia Cabang Puwokerto,” MEDIA Ekon., vol. 16, no. 2, 2016.

[16] L. P. Sinambela and S. Sinambela, Manajemen Kinerja. Jakarta: Rajawali Pers, 2019.

[17] L. W. Goni, A. Adolfina, and J. Sumarauw, "Pengaruh Pelatihan, Penempatan Kerja, Dan Kompensasi Terhadap Kinerja Karyawan Pada Pt. Bank Sulutgo Kantor Pusat Manado," J. EMBA J. Ris. Ekon. Manajemen, Bisnis dan Akunt., vol. 3, no. 4, 2016.

[18] M. Anwar, "Faktor Budaya Organisasi, Kepemimpinan Transformasional dan Kompensasi Berpengaruh Terhadap Kinerja Karyawan (Studi Pada Kantor Telkom Cabang Banjarmasin),” J. Ris. Inspirasi Manaj. dan Kewirausahaan, vol. 2, no. 1, pp. 19-37, 2018.

[19] M. P. Imam Ghozali, Aplikasi Analisis Multivariate dengan Program IBM SPSS 25. 2018.

[20] M. Y. Saleh, "Pengaruh Gaya Kepemimpinan Transformasional, Burnout Dan Quality Of Work Life Terhadap Kinerja Aparatur Sipil Negara Badan Pengelola Keuangan Dan Pendapatan Daerah Propinsi Sulawesi Barat,” Indones. J. Bus. Manag., vol. 5, no. 1, pp. 127-143, 2019.

[21] N. Darmayanti, "Pengaruh Stres Kerja, Faktor Lingkungan, dan Budaya Organisasi terhadap Kinerja Auditor Independen (Studi pada Auditor Independen Kantor Akuntan Publik di Surabaya)," J-MACC J. Manag. Account., vol. 1, no. 1, pp. 55-69, 2018. 
[22] N. I. Maulida, Y. T. Cahyono, and A. MM, "Pengaruh Motivasi Kerja, Kompensasi Kerja, Disiplin Kerja, Dan Stres Kerja Terhadap Kinerja Karyawan (Studi Kasus pada PT BPR Adipura Santosa Surakarta).” Universitas Muhammadiyah Surakarta, 2018.

[23] N. L. Suryani, "Pengaruh Kompensasi Dan Lingkungan Kerja Terhadap Kinerja Karyawan PT. Indo Tekhnoplus," JENIUS (Jurnal Ilm. Manaj. Sumber Daya Manusia), vol. 2, no. 2, pp. 260 277, 2019.

[24] P. D. Sugiyono, Metode Penelitian Bisnis: Pendekatan Kuantitatif, Kualitatif, Kombinasi, dan R\&D. 2017.

[25] R. G. SP and A. Yuniawan, "Pengaruh Gaya Kepemimpinan Transformasional, Motivasi Kerja, Dan Budaya Organisasi Terhadap Kinerja Karyawan (Studi Pada PT. BPR Arta Utama Pekalongan)," Diponegoro J. Manag., vol. 5, no. 3, pp. 251-262, 2016.

[26] R. Oroh, R. A. M. Koleangan, and Y. Mandagie, "Pengaruh Pengembangan Karir, Kompensasi, Dan Semangat Kerja Terhadap Prestasi Kerja Karyawan Pada Pt. Bpr Prisma Dana Manado,” J. EMBA J. Ris. Ekon. Manajemen, Bisnis dan Akunt., vol. 6, no. 4, 2018.

[27] S. P. Robbins and M. Coulter, Manajemen (edisi ketigabelas). 2016.

[28] S. P. Robbins and T. A. Judge, Organizational behavior: Student value edition. EE. UU.: Prentice Hall, 2014.

[29] S. R. Muhammad, A. Adolfina, and G. Lumintang, "Pengaruh Lingkungan Kerja, Kompensasi dan Beban Kerja Terhadap Kinerja Karyawan Pada Dinas Pendapatan Daerah Kota Manado,” J. EMBA J. Ris. Ekon. Manajemen, Bisnis dan Akunt., vol. 4, no. 1, 2016.

[30] T. Hermina, "Pengaruh Kompensasi dan Lingkungan Kerja terhadap Kinerja Pegawai Bank Intan Jabar (BIJ) Garut," J. Wacana Ekon., vol. 16, no. 1, pp. 28-34, 2016.

[31] V. W. Sujarweni, Kupas tuntas penelitian akuntansi dengan SPSS. 2016.

[32] Z. Kalsoom, M. A. Khan, and S. S. Zubair, "Impact of transactional leadership and transformational leadership on employee performance: A case of FMCG industry of Pakistan," Ind. Eng. Lett., vol. 8, no. 3, pp. 23-30, 2018. 